Article

\title{
Street Trees in a Chinese Forest City: Structure, Benefits and Costs
}

\author{
Xueyan Wang ${ }^{1,2}$, Jing Yao ${ }^{1}$, Shuai Yu ${ }^{1}$, Chunping Miao ${ }^{1}$, Wei Chen ${ }^{1, *}$ and Xingyuan He ${ }^{1, *}$ \\ 1 CAS Key Laboratory of Forest Ecology and Management, Institute of Applied Ecology, Chinese Academy of \\ Sciences, 72 Wenhua Road, Shenyang 110164, China; 15710591658@163.com (X.W.); \\ avril_y@foxmail.com (J.Y.); 13998265480@163.com (S.Y.); miaochunping316@163.com (C.M.) \\ 2 College of Resources and Environment, University of Chinese Academy of Sciences, Beijing 100049, China \\ * Correspondence: hexy@iae.ac.cn (X.H.); chenwei5711@163.com (W.C.)
}

Received: 7 January 2018; Accepted: 27 February 2018; Published: 1 March 2018

\begin{abstract}
Street trees provide critical ecosystem services and economic benefits that are often disregarded, due to their unknown monetary value. This study analyzed the structural characteristics of Dalian's street trees and estimated the monetary value of structural and functional benefits by i-Tree Streets. Dalian's street trees encompassed 28 species and were dominated by Ginkgo biloba, Platanus acerifolia and Sophora japonica, comprising $64.1 \%$ of a total of 57,699 trees. The age structure of street trees was distributed somewhat unevenly, with $18 \%$ young trees, $56 \%$ maturing trees, $25 \%$ mature trees and $1 \%$ old trees. These trees provide annual functional benefits valued at US $\$ 4.9$ million and delivered a benefit-cost ratio of 3.2:1. The largest values associated with energy savings and property value were $\$ 1.7$ million ( $\$ 29 /$ tree) and $\$ 1.5$ million ( $\$ 25 /$ tree), respectively. The net carbon reduction benefits were valued at $\$ 935,205$ ( $\$ 16 /$ tree). Smaller benefits resulted from air quality improvement ( $\$ 381,088$ or $\$ 7 /$ tree) and stormwater runoff $(\$ 459,457$ or $\$ 8 /$ tree). The structural benefits were valued at $\$ 130$ million, with the value of $\$ 4.5$ million for carbon storage. These findings suggested that the benefits produced by street trees were worth the management costs. Our results provide a thorough understanding of the benefits produced by street trees to policy-makers and managers, and help them make informed policies to maximize and sustain the flow of benefits.
\end{abstract}

Keywords: i-Tree Streets; ecosystem services; functional value; structural value; benefit-cost ratio

\section{Introduction}

Urbanization is a spreading phenomenon across the world and promotes economic development and poverty reduction [1]. However, rapid urbanization has disturbed the natural urban ecosystem and degraded the urban environment [2-4]. The deteriorating environment in cities has generated the urgent need for a comprehensive study of urban forests as they can alleviate environmental deterioration and improve quality of life [5-8].

Street trees (trees growing in the urban street), as part of the urban forest, play a vital role as they provide ecosystem services that improve the quality of the environment and life. Environmentally, street trees can conserve energy, sequestrate $\mathrm{CO}_{2}$, remove air pollutants, and reduce stormwater runoff [9-13]. Additionally, street trees can also increase business income and real estate values by increasing community attractiveness and recreational opportunities [14].

Numerous studies have highlighted the importance of street trees in improving the urban environment and have performed comprehensive research into their structure [15-18]. However, ecosystem services and benefits provided by street trees are often disregarded by urban managers due to their unknown monetary value [19]. In contrast, the management costs and other damage caused by street trees have been widely reported [20], driving urban managers to reduce the financial budgets of tree management. A computer program called i-Tree Streets was used to quantify the structure, 
function and values of street trees as well as their management costs. Numerous studies have been conducted in the United States, Canada, and Europe [10-12,21], which found that the benefits returned annually by street trees ranged from $\$ 1.4$ to $\$ 5.9$ for every dollar invested in management, thereby demonstrating that street trees are worth the management investment.

To date, however, limited studies exist on the structure, benefits and values of street trees in China. Since reform and opening-up, rapid urbanization, industrialization, and rural-urban migration in many Chinese cities have generated many environmental problems [22]. However, there is a lack of relevant policies and management practices regarding street trees. Inadequate financial budgets have also imposed pressures and constraints on the management of street trees [23], partly due to the poor understanding of their importance. Thus, to make Chinese cities more livable and sustainable, it is the first step in understanding the ecosystem services and economic values produced by street trees [24].

In this study, we describe the first application of i-Tree Streets in Dalian, China. Dalian, a Chinese forest city in Liaoning Province, has suffered from rapid urbanization in recent years. Our objectives were as follows: (1) to analyze the structure of street trees in Dalian; (2) to quantify their ecosystem services in monetary terms including energy savings, carbon reduction, air pollutants removal, storm water runoff reduction and property value; and (3) to estimate the costs of management. The ultimate purpose of our study was to generate objective data on the economic values produced by street trees in Dalian as the baseline data for assessing the return on management investment.

\section{Materials and Methods}

\subsection{Study Area}

This study was conducted in the main urban area (Zhongshan, Xigang, and Shahekou District) of Dalian $\left(38^{\circ} 43^{\prime}-40^{\circ} 10^{\prime} \mathrm{N}, 120^{\circ} 58^{\prime}-123^{\circ} 31^{\prime} \mathrm{E}\right)$, which approximately covers $118 \mathrm{~km}^{2}$ with a population of 1.33 million. The study area experiences a warm temperate continental monsoon climate with maritime features [25]. The mean annual temperature is $11.3^{\circ} \mathrm{C}$, and ranges from $-3.6^{\circ} \mathrm{C}$ in January to $24.5^{\circ} \mathrm{C}$ in August [26]. The mean annual precipitation is $580 \mathrm{~mm}$, mostly falling in summer (China Meteorological Data Service Center (CMDC), 1981-2010).

\subsection{Data Collection}

A field sample inventory was conducted to collect tree characteristics in the study area from June to September 2016. One hundred and twenty-one street segments were selected based on the statistical principles of random sampling, accounting for $4 \%$ of all street segments. All the trees along the selected segments were inventoried, a total of 3178 trees. Then the total tree number and information were calculated by analyzing the field data. Information regarding species, diameter at breast height (DBH), crown breadth, condition, maintenance recommendations and tasks, and other related attributes described in the i-Tree Streets Manual was recorded. Additionally, general information was also collected to aid in record management, e.g., street address, Global Positioning System (GPS) coordinates, survey date.

\section{3. $i$-Tree Streets}

In this study, i-Tree Streets (STRATUM) was used to assess the structure and function of street trees in Dalian. However, an estimate of benefits by i-Tree Streets depends on tree growth curves and other regionally specific data (e.g., geographic and economic data) for 16 climate zones in the U.S. Thus, the application of i-Tree Streets in Asian cities needs to select a "best fit" climate zone [27]. McPherson [27] proposed a method to select the best city match using four criteria: species composition, heating and cooling degree days (HDDs and CDDs), and annual precipitation. First, five candidate reference cities were selected by comparing the reference city data with Dalian. Second, the root mean squared error (RMSE) was calculated for each reference city, and the city with the lowest RMSE is the best match. The method to calculate RMSE requires two-steps: data normalization and assigning 
weight values to each criterion. We set 0.25 to species composition, 0.3 to HDD, 0.2 to CDD, and 0.25 to annual precipitation. Finally, the best match city for Dalian was Queens, New York (RMSE $=1.76$ ). Thus, the "US Northeast climate zone" was used for i-Tree Streets analysis.

Street tree species in Dalian were matched with species of the reference city using the species-to-species or genus-to-genus approach for the specific growth curves. In addition, economic data collected in China was used to calculate the annual benefits including electricity price [28], natural gas price [29], the value of $\mathrm{CO}_{2}$ reduction [30], and the median home price of Dalian. Economic data in the form of Chinese Yuan (CNY) were converted to dollars by an exchange rate of 6.9 to 1 . Other geographic and economic data of New York were also used in this study [31]. Annual benefits were calculated by using numerical modeling techniques in i-Tree Streets [10-12,21], including energy savings, carbon reduction, air pollutants removal, stormwater runoff reduction, and property value.

\subsection{Structure}

\subsubsection{Importance Value}

Importance value (IV) is a more robust indicator to reflect the street tree species dominance in a city than tree numbers alone. The importance value is calculated by the mean of three important values: percentage of total tree numbers, percentage of total leaf area, and percentage of total canopy cover $[32,33]$.

\subsubsection{Age Structure}

The age structure of street trees affects the current and future costs of management as well as the benefits produced by street trees [33]. Having an ideal age structure of street trees helps urban planners allocate the street tree management budget uniformly each year and ensure the continuity of tree canopy cover [34]. An ideal age structure of street trees should have an abundance of young trees to offset planting-related and age-related mortality [35]. In our study, street trees were classified into four classes by using $\mathrm{DBH}$, with a target proportion: $40 \%$ of young trees $(0-15 \mathrm{~cm}), 25 \%$ of maturing trees $(15-30 \mathrm{~cm}), 25 \%$ of mature trees $(30-60 \mathrm{~cm})$, and $10 \%$ of old trees $(>60 \mathrm{~cm})$ [32].

\subsection{Function and Value Calculations}

\subsubsection{Energy Savings}

Street trees in cities can reduce the energy needs of building cooling and heating by producing shade, reducing wind-speed, and reducing air temperature through tree transpiration [36-38]. Energy savings by street trees were calculated based on computer stimulations that incorporate building information, climate data, and shading effects. The building information, climate data, and energy consumption of a reference city were used in our analysis [39]. However, the average electricity (\$20.10/GJ) [28] and natural gas (\$10.17/GJ [29]) price in Dalian was used in our analysis.

\subsubsection{Carbon Reduction}

Street trees can play a critical role in mitigating global warming by reducing $\mathrm{CO}_{2}$ [10-12]. Street trees can be a sink for $\mathrm{CO}_{2}$ by directly sequestrating $\mathrm{CO}_{2}$ as tree biomass, or can reduce $\mathrm{CO}_{2}$ emissions indirectly by energy savings $[38,40,41]$. Conversely, $\mathrm{CO}_{2}$ is released by vehicles and other equipment during tree maintenance [12]. Moreover, the accumulated $\mathrm{CO}_{2}$ in tree biomass is released into the atmosphere through decomposition when trees die [12].

Carbon storage was calculated by using biomass equations for urban trees [42,43]. Annual carbon sequestration, the net increase of tree biomass, was calculated with tree species-specific growth curves and biomass equations $[42,43]$. Carbon dioxide $\left(\mathrm{CO}_{2}\right)$ released from decomposition and maintenance activities was calculated based on the decomposition rate and amount of gasoline and diesel fuel consumed in the reference city and i-Tree Streets default values. Reduced $\mathrm{CO}_{2}$ emissions by energy 
savings were calculated by energy saving benefits and $\mathrm{CO}_{2}$ emission factors. We used $\$ 150$ per ton of carbon as the value of $\mathrm{CO}_{2}$ reduction [30].

\subsubsection{Air Pollutants Removal}

Street trees can absorb gaseous pollutants $\left(\mathrm{NO}_{2}, \mathrm{O}_{3}\right.$, and $\left.\mathrm{SO}_{2}\right)$ [44] and intercept particulate matters $\left(\mathrm{PM}_{10}\right)$ [45] through leaf surfaces. Air pollutant removal by street trees was calculated by deposition velocity, meteorological data, and pollutant concentrations of $\mathrm{NO}_{2}, \mathrm{SO}_{2}$, volatile organic compounds (VOCs), $\mathrm{PM}_{10}$ and $\mathrm{O}_{3}$ to trees $[46,47]$. The deposition velocity, meteorological data, and pollutant concentrations used in our study were the i-Tree Streets default values.

Energy savings have an indirect effect in reducing air pollutant emissions $\left(\mathrm{NO}_{2}, \mathrm{PM}_{10}\right.$, VOCs and $\mathrm{SO}_{2}$ ). Reduced emissions of air pollutants resulting from energy savings were calculated using the i-Tree Streets default values.

Conversely, biogenic volatile organic compounds (BVOCs) released from trees affect ozone formation [48], thereby negatively affecting the air quality. The emission of BVOCs was calculated by the adjusted factors of emission and leaf biomass [21,49]. Air pollutant removal benefits were calculated using the default values provided for New York as follows: $\mathrm{NO}_{2}=\$ 10.10 / \mathrm{kg}, \mathrm{PM}_{10}=\$ 18.28 / \mathrm{kg}$, $\mathrm{SO}_{2}=\$ 7.66 / \mathrm{kg}, \mathrm{VOC}=\$ 5.09 / \mathrm{kg}$, and BVOCs $=\$ 5.09 / \mathrm{kg}$, values for $\mathrm{O}_{3}$ were equal to the $\mathrm{NO}_{2}$ [31]

\subsubsection{Storm Water Runoff Reduction}

The reduction of annual stormwater runoff by street trees was calculated by a numerical interception model of i-Tree Streets [50]. The crown projection area and leaf area calculated according to field inventory in Dalian were applied in this model. Furthermore, the water depth on canopy surfaces, hourly meteorological data, and annual precipitation were i-Tree Streets default values. The value of intercepted storm water was calculated using the annual control cost for New York $\left(\$ 2.11 / \mathrm{m}^{3}\right)[33]$.

\subsubsection{Property Value}

Street trees can provide a host of intangible benefits such as improving the scenic quality [51], providing refuge for urban wildlife as well as increasing the public willingness to payment [52]. However, it is difficult to quantify these intangible benefits in monetary terms. Previous studies have found that street trees could increase property values in neighborhoods where they were planted [39,53-55]. Thus, the value of these intangible benefits was estimated by the differences in the sale prices of houses. Property value benefits were best modeled by multiplying $0.88 \%$ by the city's median home sale price [56]. In our analysis, property value benefits were calculated by the distribution of the street trees, size, land use and growth rates. Data were collected from the field inventory, except the growth rates of trees which were from the reference city. The median home price of $\$ 172,246$ in Dalian was used in the model.

\subsection{Expenditure}

Street trees expenditure includes planting, maintenance (irrigation, pruning, crown thinning and removal) and management. However, Dalian lacks information on municipal tree program expenditure, and thus the management costs of street trees were estimated with an empirical value [31,57]: $\$ 20$ for a small tree $(0-15 \mathrm{~cm}), \$ 27$ for a medium tree $(15-60 \mathrm{~cm}), \$ 34$ for a large tree $(>60 \mathrm{~cm})$, and $\$ 23$ for a conifer, respectively [31]. 


\section{Results}

\subsection{Structure}

\subsubsection{Tree Numbers, Species Composition and Importance Values}

There are 57,699 street trees in Dalian, with street trees per capita of 0.04, i.e., one street tree for every 25 people. In this study, twenty-eight different species were identified (Table 1). The predominant street tree species were G. biloba (28.7\%), P. acerifolia (25.7\%) and S. japonica (9.7\%). The top ten occurring species comprised $93.7 \%$ of the total tree numbers.

Table 1. Species, tree numbers, and importance values of street trees in Dalian.

\begin{tabular}{|c|c|c|c|c|c|}
\hline Species & $\begin{array}{l}\text { Total Tree } \\
\text { Numbers }\end{array}$ & $\begin{array}{c}\% \text { of Total Tree } \\
\text { Numbers }\end{array}$ & $\begin{array}{l}\% \text { of Total } \\
\text { Leaf Area }\end{array}$ & $\begin{array}{c}\% \text { of Total } \\
\text { Canopy Cover }\end{array}$ & $\begin{array}{c}\text { Importance } \\
\text { Value }\end{array}$ \\
\hline Platanus acerifolia & 14,836 & 25.7 & 33.8 & 36.8 & 32.1 \\
\hline Ginkgo biloba & 16,537 & 28.7 & 9.3 & 14.2 & 17.4 \\
\hline Sophora japonica & 5579 & 9.7 & 10.4 & 7.2 & 9.1 \\
\hline Populus canadensis & 2026 & 3.5 & 11.4 & 9.3 & 8.1 \\
\hline Platanus occidentalis & 3608 & 6.3 & 7.3 & 8.0 & 7.2 \\
\hline Robinia pseudoacacia & 2710 & 4.7 & 8.1 & 7.4 & 6.7 \\
\hline Salix babylonica & 2659 & 4.6 & 6.0 & 4.4 & 5.0 \\
\hline Fraxinus chinensis & 2490 & 4.3 & 4.3 & 4.1 & 4.2 \\
\hline Sabina chinensis & 2607 & 4.5 & 1.3 & 1.0 & 2.3 \\
\hline Salix matsudana & 986 & 1.7 & 2.9 & 2.2 & 2.3 \\
\hline Acer negundo & 840 & 1.5 & 1.4 & 1.2 & 1.3 \\
\hline Cedrus deodara & 418 & 0.7 & 0.9 & 1.0 & 0.9 \\
\hline Eucommia ulmoides & 407 & 0.7 & 0.7 & 0.7 & 0.7 \\
\hline Populus alba & 276 & 0.5 & 0.7 & 0.7 & 0.6 \\
\hline Sabina chinensis $K$. & 535 & 0.9 & 0.2 & 0.3 & 0.5 \\
\hline Koelreuteria paniculata & 226 & 0.4 & 0.1 & 0.2 & 0.3 \\
\hline Acer truncatum & 188 & 0.3 & 0.2 & 0.2 & 0.2 \\
\hline Liriodendron chinense & 129 & 0.2 & 0.2 & 0.2 & 0.2 \\
\hline Paulownia tomentosa & 47 & 0.1 & 0.2 & 0.2 & 0.1 \\
\hline Cerasus serrulata & 108 & 0.2 & 0.1 & 0.1 & 0.1 \\
\hline Pyrus ussuriensis & 57 & 0.1 & 0.1 & 0.1 & 0.1 \\
\hline Morus alba & 70 & 0.1 & 0.1 & 0.1 & 0.1 \\
\hline Diospyros lotus & 73 & 0.1 & 0.1 & 0.1 & 0.1 \\
\hline Platycladus orientalis & 96 & 0.2 & 0.0 & 0.0 & 0.1 \\
\hline Ailanthus altissima & 50 & 0.1 & 0.1 & 0.1 & 0.1 \\
\hline Albizzia julibrissin & 64 & 0.1 & 0.0 & 0.1 & 0.1 \\
\hline Evodia daniellii & 64 & 0.1 & 0.0 & 0.1 & 0.1 \\
\hline Armeniaca sibirica & 13 & 0.0 & 0.0 & 0.0 & 0.0 \\
\hline Total trees & 57,699 & 100.0 & 100.0 & 100.0 & 100.0 \\
\hline
\end{tabular}

The predominant street tree species in Dalian represented $93.7 \%$ of the total tree numbers, $94.9 \%$ of the total leaf area, and $94.6 \%$ of the total canopy cover. The total importance values (IVs) of these predominant street trees was 94.4 (Table 1). Of these species, Dalian relied most on P. acerifolia, with the highest IV of 32.1. This made P. acerifolia twice as significant as G. biloba $(\mathrm{IV}=17.4)$, and three times more significant than $S$. japonica $(I V=9.1)$. The importance values of young trees and small-stature trees were relatively lower due to their relatively small leaf area and canopy cover such as $S$. chinensis $(\mathrm{IV}=2.3)$.

\subsubsection{Age Structure}

The age structure of street trees in Dalian was distributed somewhat unevenly, with $18 \%$ of young trees $(0-15 \mathrm{~cm}), 56 \%$ of maturing trees $(15-30 \mathrm{~cm}), 25 \%$ of mature trees $(30-60 \mathrm{~cm})$, and $1 \%$ of old trees $(>60 \mathrm{~cm})$ (Figure 1). Of the ten dominant tree species, only S. chinensis exceeded the $40 \%$ ideal 
in the young trees (65\%) but had inadequate representation in the mature trees (Figure 1). G. biloba, P. acerifolia, S. japonica, P. occidentalis, and P. canadensis dominated in the maturing and mature trees and had inadequate representation in the young trees.

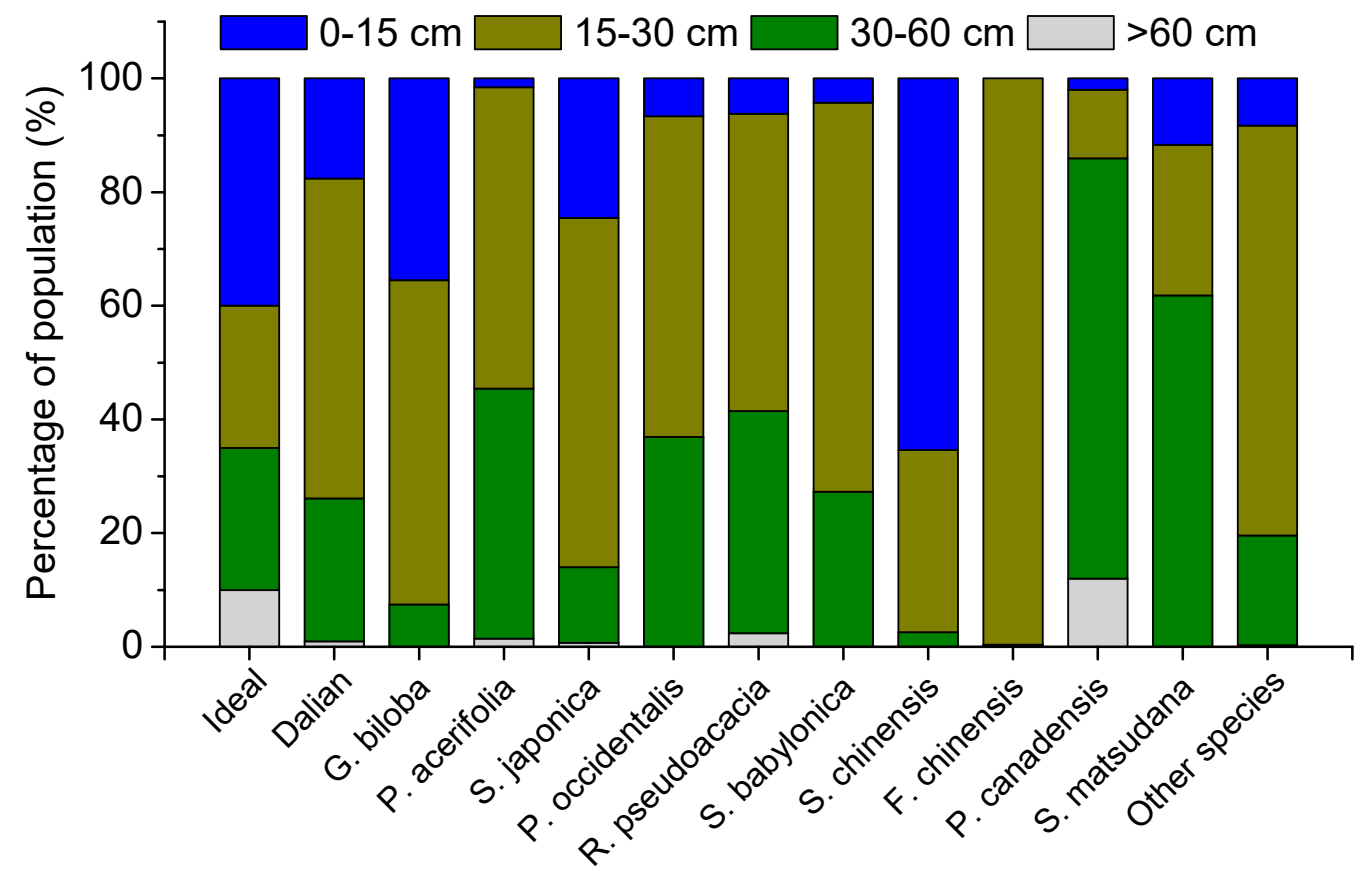

Figure 1. The age structure of predominant street tree species compared to the ideal. Note: "Dalian" represents the total street trees.

\subsection{Function and Value}

\subsubsection{Energy Savings}

Annual electricity and natural gas saving by street trees have been valued as $12,339 \mathrm{GJ}^{\text {year }}{ }^{-1}$ $(\$ 248,176)$ and $141,011 \mathrm{GJ} \mathrm{year}^{-1}(\$ 1,436,228)$, respectively (Table 2$)$. The total energy saving benefits provided by street trees in Dalian were $\$ 1.7$ million annually, or a citywide average of $\$ 29.2 /$ tree. P. acerifolia (35.2\%), G. biloba (15.3\%), R. pseudoacacia (7.9\%), S. japonica (7.8\%), P. occidentalis (7.8\%), and P. canadensis $(7.7 \%)$ produced great benefits.

Table 2. Annual energy savings benefits produced by predominant street trees.

\begin{tabular}{lccccccc}
\hline \multicolumn{1}{c}{ Species } & $\begin{array}{c}\text { Total Electricity } \\
\mathbf{( G J )}\end{array}$ & $\begin{array}{c}\text { Electricity } \\
\mathbf{( \$ )}\end{array}$ & $\begin{array}{c}\text { Total Natural } \\
\text { Gas (GJ) }\end{array}$ & $\begin{array}{c}\text { Natural } \\
\text { Gas (\$) }\end{array}$ & $\begin{array}{c}\text { Total (\$) } \\
\text { (\$) of } \\
\text { Total \$ }\end{array}$ & $\begin{array}{c}\text { Avg. } \\
\mathbf{\$} / \text { Tree }\end{array}$ \\
\hline G. biloba & 1778 & 35,770 & 21,804 & 222,081 & 257,851 & 15.3 & 15.6 \\
P. acerifolia & 4496 & 90,426 & 49,404 & 503,188 & 593,615 & 35.2 & 40.0 \\
S. japonica & 894 & 17,976 & 11,116 & 113,214 & 131,191 & 7.8 & 23.5 \\
P. occidentalis & 980 & 19,710 & 10,941 & 111,441 & 131,151 & 7.8 & 36.3 \\
R. pseudoacacia & 1008 & 20,271 & 11,147 & 113,530 & 133,801 & 7.9 & 49.4 \\
S. babylonica & 556 & 11,190 & 6623 & 67,460 & 78,650 & 4.7 & 29.6 \\
S. chinensis & 117 & 2353 & 1438 & 14,650 & 17,003 & 1.0 & 6.5 \\
F. chinensis & 488 & 9814 & 6256 & 63,716 & 73,530 & 4.4 & 29.5 \\
P. canadensis & 1018 & 20,478 & 10,685 & 108,832 & 129,310 & 7.7 & 63.8 \\
S. matsudana & 280 & 5636 & 3101 & 31,585 & 37,221 & 2.2 & 38.1 \\
Other species & 723 & 14,552 & 8496 & 86,531 & 101,083 & 6.0 & 27.6 \\
Total & 12,339 & 248,176 & 141,011 & $1,436,228$ & $1,684,404$ & 100.0 & 29.2 \\
\hline
\end{tabular}

On a per tree basis, large-stature trees produced the greatest benefits such as P. acerifolia (\$40.0), R. pseudoacacia (\$49.4), P. occidentalis (\$36.3), P. canadensis (\$63.8), and S. matsudana (\$38.1). Small-stature 
trees with less leaf area and canopy cover such as S. chinensis (\$6.5) and G. biloba (\$15. 6) produced energy saving benefits well below the average value (\$29.2).

\subsubsection{Carbon Reduction}

Dalian's street trees were estimated to store $29,873 \mathrm{t}(\$ 4,478,353)$ of $\mathrm{CO}_{2}$ that was accumulated in tree biomass (Table 3). P. acerifolia (34.6\%), P. canadensis (14.9\%), G. biloba (11.2\%), S. japonica $(7.7 \%)$, and R. pseudoacacia $(7.6 \%)$ stored the most $\mathrm{CO}_{2}$.

The annual amount of $\mathrm{CO}_{2}$ sequestered by street trees was $2317 \mathrm{t}(\$ 347,358)$ (Table 3). Meantime, the annual avoided $\mathrm{CO}_{2}$ emissions from energy savings totaled $4683 \mathrm{t}(\$ 702,073)$. Annual release of $\mathrm{CO}_{2}$ from tree maintenance activities and decomposition was $762 \mathrm{t}$, valued $\$ 114,226$ (Table 3). Therefore, net annual $\mathrm{CO}_{2}$ removed by street trees totaled $36,111 \mathrm{t}$. The monetary value associated with $\mathrm{CO}_{2}$ reduction was $\$ 935,205$ (Table 3). P. acerifolia $(35.4 \%)$, G. biloba $(14.8 \%)$, R. pseudoacacia $(8.2 \%)$, P. canadensis $(8.2 \%)$, S. japonica $(7.7 \%)$, and P. occidentalis $(7.7 \%)$ produced the greatest net benefits.

On a per tree basis, the carbon reduction benefits were $\$ 16.2$ on average. P. canadensis produced the greatest net carbon reduction benefits, valued at nearly $\$ 38 /$ tree. P. acerifolia $(\$ 22.3)$ and $R$. pseudoacacia (\$28.4) were also important contributors to carbon reduction. G. biloba produced net benefits valued at $\$ 8.4 /$ tree, well below the average value (\$16.2).

\subsubsection{Air Pollutants Removal}

The annual air pollutants absorbed $\left(\mathrm{NO}_{2}, \mathrm{O}_{3}\right.$, and $\left.\mathrm{SO}_{2}\right)$ or intercepted (small particulate matter $\mathrm{PM}_{10}$ ) directly by Dalian's street trees totaled $16.3 \mathrm{t}$, for a value of $\$ 193,972$ (Table 4). P. acerifolia removed the most air pollutants, accounting for $36.1 \%$ of the total removing benefits. Due to the largest proportion of the total tree population, G. biloba (13.9\%) was the next greatest contributors of removing air pollutants.

Indirectly avoided emissions of air pollutants resulted from energy savings that amounted to $21.9 \mathrm{t} \mathrm{year}^{-1}$ with an implied value of $\$ 209,855$ (Table 4). P. acerifolia, P. canadensis, G. biloba, S. japonica and $R$. pseudoacacia had the greatest contribution to avoiding air pollutants emissions by reducing energy consumption, accounting for $74.3 \%$ of the avoided benefits.

About $4.5 \mathrm{t}_{\text {year }}{ }^{-1}$ BVOCs were released by trees, offsetting the total benefits by $\$ 22,740$ (Table 4 ). The species that emitted more BVOCs were P. acerifolia (62.8\%), P. occidentalis (13.5\%), and G. biloba (6.5\%).

The net benefits of air pollutant removal were valued at $\$ 381,088 /$ year or $\$ 6.6 /$ tree (Table 4 ). P. acerifolia (34.4\%) and G. biloba $(14.8 \%)$ produced the greatest contribution to air pollutant removal. On a per tree basis, however, $R$. pseudoacacia (\$11.5) and P. canadensis (\$17.1) produced the greatest benefits. 
Table 3. Annual carbon reduction benefits produced by predominant street trees.

\begin{tabular}{|c|c|c|c|c|c|c|c|c|c|c|c|c|c|}
\hline Species & $\begin{array}{c}\text { Total Stored } \\
\mathrm{CO}_{2}(\mathrm{t})\end{array}$ & $\begin{array}{c}\text { Total } \\
\text { Stored (\$) }\end{array}$ & $\begin{array}{c}\text { Sequestered } \\
(t)\end{array}$ & $\begin{array}{l}\text { Sequestered } \\
\text { (\$) }\end{array}$ & $\begin{array}{l}\text { Decomposition } \\
\text { Release (t) }\end{array}$ & $\begin{array}{c}\text { Maintenance } \\
\text { Release (t) }\end{array}$ & $\begin{array}{c}\text { Total } \\
\text { Release (\$) }\end{array}$ & $\begin{array}{c}\text { Avoided } \\
\text { (t) }\end{array}$ & $\begin{array}{c}\text { Avoided } \\
\text { (\$) }\end{array}$ & $\begin{array}{c}\text { Net } \\
\text { Total (t) }\end{array}$ & $\begin{array}{c}\text { Total } \\
\text { (\$) }\end{array}$ & $\begin{array}{c}\% \text { of } \\
\text { Total } \$\end{array}$ & $\begin{array}{l}\text { Avg. } \\
\text { \$/Tree }\end{array}$ \\
\hline P. acerifolia & 10,334 & $1,549,168$ & 726 & 108,774 & -158 & -64 & $-33,217$ & 1706 & 255,810 & 12,544 & 331,368 & 35.4 & 22.3 \\
\hline G. biloba & 3340 & 500,740 & 368 & 55,183 & -75 & -45 & $-17,928$ & 675 & 101,191 & 4264 & 138,446 & 14.8 & 8.4 \\
\hline R. pseudoacacia & 2262 & 339,043 & 194 & 29,115 & -51 & -12 & -9335 & 383 & 57,344 & 2776 & 77,124 & 8.2 & 28.4 \\
\hline P. canadensis & 4450 & 667,104 & 229 & 34,327 & -88 & -13 & $-15,148$ & 386 & 57,932 & 4964 & 77,111 & 8.2 & 38.1 \\
\hline S. japonica & 2288 & 342,973 & 206 & 30,817 & -49 & -17 & -9811 & 339 & 50,854 & 2767 & 71,860 & 7.7 & 12.9 \\
\hline P. occidentalis & 1990 & 298,333 & 153 & 23,011 & -34 & -14 & -7148 & 372 & 55,760 & 2468 & 71,622 & 7.7 & 19.8 \\
\hline S. babylonica & 1501 & 225,089 & 118 & 17,756 & -34 & -10 & -6492 & 211 & 31,655 & 1788 & 42,918 & 4.6 & 16.1 \\
\hline F. chinensis & 566 & 84,821 & 66 & 9844 & -13 & -8 & -3063 & 185 & 27,763 & 796 & 34,544 & 3.7 & 13.9 \\
\hline S. matsudana & 962 & 144,169 & 55 & 8230 & -22 & -4 & -3902 & 106 & 15,943 & 1097 & 20,272 & 2.2 & 20.8 \\
\hline A. negundo & 569 & 85,354 & 42 & 6317 & -13 & -3 & -2344 & 59 & 8827 & 655 & 12,801 & 1.4 & 15.2 \\
\hline Other species & 1611 & 241,558 & 160 & 23,985 & -27 & -11 & -5839 & 260 & 38,994 & 1992 & 57,140 & 6.1 & 10.5 \\
\hline Total & 29,873 & $4,478,353$ & 2317 & 347,358 & -561 & -201 & $-114,226$ & 4683 & 702,073 & 36,111 & 935,205 & 100.0 & 16.2 \\
\hline
\end{tabular}

Table 4. Annual air pollutants removal benefits produced by predominant street trees.

\begin{tabular}{|c|c|c|c|c|c|c|c|c|c|c|}
\hline Species & Deposition (kg) & Deposition (\$) & Avoided (kg) & Avoided (\$) & BVOCs Emissions (kg) & BVOCs Emissions (\$) & Total (kg) & Total (\$) & $\%$ of Total \$ & Avg. \$/Tree \\
\hline P. acerifolia & 5911 & 70,094 & 7893 & 75,444 & -2804 & $-14,280$ & 11,000 & 131,258 & 34.4 & 8.8 \\
\hline G. biloba & 2277 & 26,997 & 3235 & 31,010 & -288 & -1469 & 5223 & 56,538 & 14.8 & 3.4 \\
\hline P. canadensis & 1495 & 17,730 & 1763 & 16,826 & 0 & 0 & 3258 & 34,556 & 9.1 & 17.1 \\
\hline R. pseudoacacia & 1190 & 14,111 & 1773 & 16,949 & 0 & 0 & 2963 & 31,060 & 8.2 & 11.5 \\
\hline S. japonica & 1177 & 13,976 & 1633 & 15,666 & -170 & -864 & 2641 & 28,778 & 7.6 & 5.2 \\
\hline P. occidentalis & 1280 & 15,178 & 1729 & 16,534 & -603 & -3070 & 2406 & 28,641 & 7.5 & 7.9 \\
\hline S. babylonica & 720 & 8547 & 1002 & 9599 & -98 & -499 & 1624 & 17,647 & 4.6 & 6.6 \\
\hline F. chinensis & 653 & 7748 & 901 & 8649 & 0 & 0 & 1554 & 16,397 & 4.3 & 6.6 \\
\hline S. matsudana & 364 & 4328 & 493 & 4713 & -46 & -236 & 811 & 8805 & 2.3 & 9.0 \\
\hline A. negundo & 209 & 2473 & 284 & 2723 & -42 & -213 & 451 & 4983 & 1.3 & 5.9 \\
\hline Other species & 1070 & 12,790 & 1226 & 11,742 & -414 & -2108 & 1883 & 22,424 & 5.9 & 4.1 \\
\hline Total & 16,345 & 193,972 & 21,932 & 209,855 & -4465 & $-22,740$ & 33,812 & 381,088 & 100.0 & 6.6 \\
\hline
\end{tabular}




\subsubsection{Stormwater Runoff Reduction}

Dalian's street trees intercepts approximately $217,404 \mathrm{~m}^{3}$ of rainfall annually. The total stormwater runoff reduction benefits to Dalian were $\$ 459,457$, with an average value of $\$ 8.0 /$ tree (Table 5). The most effective species on a per tree basis were P. acerifolia ( $\$ 10.8 /$ tree), P. canadensis ( $\$ 23.0 /$ tree), R. pseudoacacia ( $\$ 12.9 /$ tree), and S. matsudana (\$12.3/tree). The most important tree species for stormwater interception were P. acerifolia (34.9\%), G. biloba (11.4\%), P. canadensis (10.2\%), S. japonica $(9.0 \%)$, and R. pseudoacacia (7.6\%), accounting for $73.1 \%$ of stormwater runoff reduction benefits.

Table 5. Annual stormwater runoff reduction benefits of predominant street trees.

\begin{tabular}{lcccc}
\hline \multicolumn{1}{c}{ Species } & Total Rainfall Interception $\left.\mathbf{( m}^{\mathbf{3}}\right)$ & Total $\mathbf{( \$ )}$ & $\mathbf{\%}$ of Total \$ & Avg. \$/Tree \\
\hline P. acerifolia & 75,974 & 160,561 & 34.9 & 10.8 \\
G. biloba & 24,776 & 52,360 & 11.4 & 3.2 \\
P. canadensis & 22,077 & 46,657 & 10.2 & 23.0 \\
S. japonica & 19,611 & 41,445 & 9.0 & 7.4 \\
R. pseudoacacia & 16,492 & 34,853 & 7.6 & 12.9 \\
P. occidentalis & 16,388 & 34,633 & 7.5 & 9.6 \\
S. babylonica & 11,656 & 24,633 & 5.4 & 9.3 \\
F. chinensis & 8876 & 18,758 & 4.1 & 7.5 \\
S. matsudana & 5693 & 12,031 & 2.6 & 12.3 \\
S. chinensis & 3476 & 7345 & 1.6 & 2.8 \\
Other species & 12,387 & 26,179 & 5.7 & 7.2 \\
Total & 217,404 & 459,457 & 100.0 & 8.0 \\
\hline
\end{tabular}

\subsubsection{Property Value}

The estimated property value benefits were $\$ 1,453,175$, for an average of $\$ 25.2 /$ tree (Table 6). P. acerifolia (27.2\%), G. biloba (15.7\%), S. japonica (11.0\%), R. pseudoacacia (9.9\%), and P. canadensis (7.9\%) produced the highest property value benefits.

Table 6. Property value benefits produced by predominant street trees.

\begin{tabular}{lccc}
\hline \multicolumn{1}{c}{ Species } & Total $\mathbf{( \$ )}$ & \% of Total \$ & Avg. \$/Tree \\
\hline P. acerifolia & 395,614 & 27.2 & 26.7 \\
G. biloba & 227,539 & 15.7 & 13.8 \\
S. japonica & 159,430 & 11.0 & 28.6 \\
R. pseudoacacia & 144,095 & 9.9 & 53.2 \\
P. canadensis & 115,050 & 7.9 & 56.8 \\
P. occidentalis & 92,522 & 6.4 & 25.6 \\
S. babylonica & 73,816 & 5.1 & 27.8 \\
F. chinensis & 72,970 & 5.0 & 29.3 \\
S. chinensis & 56,390 & 3.9 & 21.6 \\
S. matsudana & 29,650 & 2.0 & 30.4 \\
Other species & 86,099 & 5.9 & 23.6 \\
Total & $1,453,175$ & 100 & 25.2 \\
\hline
\end{tabular}

\subsubsection{Total Annual Benefits and Benefit-Cost Ratio (BCR)}

The total benefits of Dalian's street trees were $\$ 4,913,328$ annually, or $\$ 85.2 /$ tree (Table 7). Over half $(70 \%)$ of the total benefits provided to the city residents were environmental services. Energy savings accounted for $49 \%$ of the environmental benefits and $34 \%$ of the total benefits. The second largest benefits were property value benefits, accounting for $30 \%$ of the total benefits. The reduction of $\mathrm{CO}_{2}$ accounted for $27 \%$ of the environmental benefits and $19 \%$ of the total benefits. Air pollutant removal $(11 \%)$ and stormwater runoff reduction $(13 \%)$ provided the lowest contribution to the environmental benefits and accounted for $8 \%$ and $9 \%$ of the total benefits, respectively. 
The top 10 occurring species comprised $94.0 \%$ of the total annual benefits. P. acerifolia was the most valuable to the city (32.8\% of total benefits). G. biloba (14.9\%), S. japonica (8.8\%), R. pseudoacacia $(8.6 \%)$, P. canadensis $(8.2 \%)$, and P. occidentalis $(7.3 \%)$ also produced significant benefits to Dalian. On a per tree basis, P. canadensis (\$199), R. pseudoacacia (\$155), and P. acerifolia (\$109) produced significant benefits. Additionally, G. biloba produced the least benefits at $\$ 44 /$ tree.

The management costs of Dalian's street trees are approximately $\$ 1.5$ million annually or $\$ 26.5 /$ tree. Therefore, the annual net benefits were $\$ 3.4$ million, at an average $\$ 58.7 /$ tree (Table 7). City residents received $\$ 3.2$ in benefits from every $\$ 1$ invested in tree management, i.e., the benefit-cost ratio was 3.2:1.

Table 7. Benefits and costs for Dalian's street trees.

\begin{tabular}{cccc}
\hline Benefits & Total (\$) & \$/Tree & \% of Total Benefits \\
\hline Energy & $1,684,404$ & 29.2 & 34.3 \\
$\mathrm{CO}_{2}$ & 935,205 & 16.2 & 19.0 \\
Air Quality & 381,088 & 6.6 & 7.8 \\
Stormwater & 459,457 & 8.0 & 9.4 \\
Property value & $1,453,175$ & 25.2 & 29.6 \\
Total benefits & $4,913,328$ & 85.2 & \\
Total costs & $1,526,302$ & 26.5 & \\
Net benefits & $3,387,026$ & 58.7 & \\
Benefit-cost ratio & 3.2 & & \\
\hline
\end{tabular}

\subsubsection{Structural Value}

The structural value of Dalian's street trees was $\$ 130$ million (Table S1), which was estimated by the costs of replacing all street trees with trees of the same status. The average structural value per tree was $\$ 2250$. P. acerifolia accounted for nearly $44 \%$ of the total structural value, followed by G. biloba (20.6\%), S. japonica (8.4\%), P. occidentalis (5.9\%), R. pseudoacacia (5.4\%), and P. canadensis (3.5\%).

\section{Discussion}

\subsection{Structure}

Dalian's street trees were estimated to be 57,699 (Table 1). The street trees per capital were 0.04, lower than that in Europe and U.S. cities $[10,11,21,41]$, reflecting the high population density in Dalian. The species abundance of street trees in Dalian (28 species) was approximately the same as other Chinese cities such as Shenyang ( 23 species), Lhasa ( 24 species) and Qingdao ( 43 species) $[18,58,59]$. However, the species abundance of street trees in these Chinese cities was smaller than other foreign cities (e.g., 105 to 214 species in Californian cities, 78 species in Lisbon, 130 species in Pittsburgh, 108 species in Bangalore, and 61 species in the Eastern Cape) $[11,12,15,16,60]$, indicating that the species configuration lacks rationality in these Chinese cities. In addition, a diversity of street tree species is important to enhance the stability of street trees and protect street trees against the possibility of catastrophic losses [61]. Santamour [55] proposed a widely accepted diversity rule that any street tree species should not account for more than $10 \%$ of the total tree numbers, any one genus more than $20 \%$, and any one family more than $30 \%$. This meant that an ideal street tree of one city should not be dominated by a few species. In this study, however, the predominant tree species, G. biloba $(28.7 \%)$ and P. acerifolia (25.7\%), exceeded the accepted diversity rule. Another robust indicator, the importance value, was used to reflect the importance of tree species [32,33]. The importance values of the top 10 occurring species was 94.4, further indicating that Dalian's street trees were much too dependent on these few species. Overreliance on G. biloba and P. acerifolia has generated a serious management concern and made street trees vulnerable to catastrophic losses caused by plant diseases, insect pests, or other stressors, highlighting the need to diversify street tree species composition. 
Previous studies have highlighted the importance of age structure in sustaining the stability and flow of benefits of street trees by offsetting the planting-related and age-related mortality $[32,33,35]$. However, Dalian's street trees failed to approach this ideal age distribution, with $18 \%$ of young trees, $56 \%$ of maturing trees, $25 \%$ of mature trees, and $1 \%$ of old trees (Figure 1). Millward and Sabir [57] suggested that large trees were responsible for the most of the benefits provided by street trees. Thus, the benefits provided by street trees may be approaching the peak or have peaked in the current age structure. However, given the concerning fact when comparing the ideal proportion of younger trees $(40 \%)$ to that of the current population $(18 \%)$, this indicates that the age structure of street trees in Dalian will develop towards the mature size classes without an inadequate number of young trees. With regard to more old trees, the urban planner will face greater management costs in order to sustain the high and sustained flow of benefits.

\subsection{Function and Value}

Street trees are a valuable green infrastructure and provide city residents with benefits in the form of functional value, i.e., energy savings, carbon reduction, air pollutants removal, storm water runoff reduction, and property value $[11,12,21]$. Numerous studies have demonstrated the monetary values of street trees [10-12,21]. Most Chinese cities, however, lack corresponding policies and management practices for street trees due to their unknown monetary values. Using i-Tree Streets, the total annual benefits provided to the city residents were estimated at $\$ 4,913,328$ (Table 7), presenting the ecological and economic values of street trees to the urban planner and city residents of Dalian. In addition, of the total annual benefits, over half $(70 \%)$ were environmental services in Dalian, which were different with other foreign cities with the most important benefit of property value (accounting for $43-83 \%$ of the total benefits) $[10-12,21,33,60,62]$. The most important environmental services were energy saving and carbon reduction, which might be attributed to the rapid urbanization and economic development of China. Nevertheless, the property value benefits still accounted for $30 \%$ of the total benefits. It is no doubt that street trees would increase sale prices when urban planners and city residents realize the monetary value of ecosystem services provided by street trees.

Management practices for street trees are costly to sustain the flow of benefits [11,12,21]. The management costs of street trees were $\$ 1.5$ million in Dalian. As shown in our results, however, a benefit-cost ratio of 3.2 for Dalian demonstrated that the collective benefits produced by street trees were worth the costs of management. Compared to other cities, Dalian's BCR of 3.2 was greater than Modesto Santa (1.8), Monica (1.5), and Pittsburgh (2.9), but less than Lisbon (4.5), New York City (5.6), and Indianapolis $(6.1)[10,12,33,60,62]$. However, one fact that should be considered is that the age structure of street trees in Dalian will develop towards the mature size classes. Furthermore, $94.0 \%$ of total annual benefits were produced by the top ten street tree species in Dalian, and nine out of ten predominant street tree species were dominated by mature trees. The removal and replacement of old trees would reduce the net benefits and the benefit-cost ratio.

\subsection{Management Implications}

Dalian's street trees provide substantial benefits to the city residents and improve the quality of life. Additionally, the investment in the management of these public assets yields a large return economically, environmentally, and socially. However, Dalian still faces management challenges to optimize the structure of street trees to maximize and sustain the flow of benefits.

First, the distribution of Dalian's street trees was skewed towards a few species. Overreliance on G. biloba and P. acerifolia will remain a management concern due to the potential for catastrophic losses caused by plant diseases, insect pests, or other stressors. In addition, G. biloba produces less benefit at $\$ 44$ per tree (Table S2). Large-stature trees such as S. matsudana (\$111/tree) and P. alba (\$140/tree), are good choices as alternatives to Ginkgo biloba and Platanus acerifolia (Table S2). These results highlight the need to diversify the species composition through new tree plantings to reduce dependence on G. biloba and P. acerifolia and to protect against catastrophic losses. Second, the age structure of Dalian's 
street trees is non-ideal as it lacks young trees (18\%). In particular, of the five dominant tree species, all species (G. biloba, P. acerifolia, S. japonica, P. occidentalis and P. canadensis) exceeded the $50 \%$ ideal in the maturing and mature trees $(15-60 \mathrm{~cm})$. Although the current age structure of street trees tends to produce more benefits, more mature trees face greater maintenance costs. In addition, without planting young trees planting, the total benefits produced by street trees are vulnerable to fluctuations caused by the death and decline of old trees [34]. Thus, the municipality of Dalian needs to build an ideal age structure of street trees through new tree plantings to ensure a sustainable street tree structure.

\subsection{Limitations and Uncertainty}

In this study, the benefits produced by street trees were calculated on the basis of tree growth curves and other regionally specific data from "best fit" climate zone in the U.S. Thus, the benefits were approximations in this study due to the extrapolation of data from the reference city to Dalian as conducting a reference city analysis cost an estimated $\$ 250,000$ per city when i-Tree Streets was used outside the U.S. [27]. However, we have done the following works of matching tree species and collecting local data in order to increase the accuracy of our results. First, matching street tree species is a priority as tree benefits are linked to species-specific size variables [27]. Despite the lack of growth curves for Dalian street trees, $63.3 \%$ tree species were matched with the reference city we selected. It was noted that the predominant species in Dalian were the species to species match with the reference city, e.g., P. acerifolia, G. biloba, S. japonica. For the remaining species, which were not available matched in species level, a genus to genus match approach was used [27]. Thus, the accuracy of the benefits calculated by i-Tree Streets increased with tree composition matching.

Second, we collected the benefit prices as best as we could including the average electricity [28], natural gas [29], the value of $\mathrm{CO}_{2}$ reduction [30], and the median home price of Dalian to increase the accuracy of the results. Further study is required to obtain other benefit prices and geographic data to make the results more accurate.

Furthermore, there was an uncertainty in the estimates of the management costs of street trees. In this analysis, the management costs of street trees were estimated by an empirical value $[31,57]$ due to lack of information regarding the municipal tree program expenditures in Dalian. Further precision of the management costs in this study is needed to understand the actual annual cost of maintaining street trees.

\section{Conclusions}

This study analyzed the structural characteristics of Dalian's street trees and estimated the monetary value of ecosystem services provided to the city residents through using i-Tree Streets. Dalian's street trees comprised a wide range of species; of the 57,699 trees present, 28 species were identified. The most predominant species were G. biloba, P. acerifolia and S. japonica, comprising $64.1 \%$ of the total tree numbers. These results indicated that street tree species composition faces a management concern and was vulnerable to catastrophic losses caused by plant diseases, insect pests, or other stressors. In addition, Dalian's street trees were distributed somewhat unevenly with fewer young trees $(18 \%)$, a large proportion of maturing and mature trees $(81 \%)$, and a deficit of old trees $(1 \%)$. Although the current distribution of street trees provides more benefits, street trees with more mature trees will face greater maintenance costs without new plantings taking place.

Dalian's street trees provided substantial structural and functional benefits. The structural value of Dalian's street trees was approximately $\$ 130$ million, with a value of $\$ 4.5$ million for carbon storage. The annual functional benefits of Dalian's street trees were $\$ 4.9$ million ( $\$ 85 /$ tree). Street trees increased property value with an estimated annual value of $\$ 1.5$ million ( $\$ 25 /$ tree). The annual energy saving benefits from all street trees in Dalian was $\$ 1.7$ million ( $\$ 29 /$ tree). The net carbon dioxide reduction benefit was valued at $\$ 0.9$ million ( $\$ 16 /$ tree). Smaller benefits resulted from air quality ( $\$ 0.4$ million or $\$ 7 /$ tree) and stormwater runoff ( $\$ 0.5$ million or $\$ 8 /$ tree). However, city managers should also consider the management costs of street trees. The municipality of Dalian spent approximately 
$\$ 1.5$ million ( $\$ 26 /$ tree) annually on tree management. The annual net benefits were $\$ 3.4$ million, an average of $\$ 59 /$ tree. City residents received $\$ 3.2$ in benefits from every $\$ 1$ invested in management costs of street trees. Therefore, our results suggested that the benefits produced by street trees were worth the costs of management. However, the current state of Dalian's street trees is not sustainable due to the unreasonable structure. Managers and policy-makers must realize that street trees are a vulnerable resource and require constant care in order to continuously generate benefits in the future.

Supplementary Materials: The following are available online at www.mdpi.com/2071-1050/10/3/674/s1, Table S1: Structural values of Dalian's street trees, Table S2: Functional values produced by Dalian's street trees.

Acknowledgments: The work was financially supported by the National Natural Science Foundation of China (No. 41730647 and 41671185). We would like to thank the many students and field staff who assisted with the surveying and sampling. W.D. Xu and D.L. Tao from the Institute of Applied Ecology (CAS) provided highly useful edits on the revision of this paper. We would like to express our sincere thanks to the reviewers and editor for the constructive and positive comments, which have greatly improved the quality of this paper. In addition, we would like to thank MDPI for the English language editing.

Author Contributions: Xueyan Wang, Wei Chen and Xingyuan He conceived the study. Xueyan Wang, Wei Chen, Shuai Yu and Chunping Miao collected data. Xueyan Wang and Jing Yao analyzed the data, and Xueyan Wang led the writing of the paper with substantial input from all co-authors.

Conflicts of Interest: The authors declare no conflict of interest.

\section{Abbreviations}

$\begin{array}{ll}\text { HDDs } & \text { Heating degree days } \\ \text { CDDs } & \text { Cooling degree days } \\ \text { DBH } & \text { Diameter at breast height } \\ \text { BVOCs } & \text { Biogenic volatile organic compounds } \\ \text { IV } & \text { Importance value } \\ \text { BCR } & \text { Benefit-cost ratio }\end{array}$

\section{References}

1. United Nations. World Urbanization Prospects; The 2014 Revision; United Nations: New York, NY, USA, 2014; Available online: http:/ / esa.un.org/unpd/wup/Highlights/WUP2014-Highlights.pdf (accessed on 15 March 2017).

2. Alberti, M.; Marzluff, J.M. Ecological resilience in urban ecosystems: Linking urban patterns to human and ecological functions. Urban Ecosyst. 2004, 7, 241-265. [CrossRef]

3. Gregg, J.W.; Jones, C.G.; Dawson, T.E. Urbanization effects on tree growth in the vicinity of New York City. Nature 2003, 424, 183-187. [CrossRef] [PubMed]

4. Roy, S.; Byrne, J.; Pickering, C. A systematic quantitative review of urban tree benefits, costs, and assessment methods across cities in different climatic zones. Urban For. Urban Green. 2012, 11, 351-363. [CrossRef]

5. Cai, C.; Peng, Z.; Wang, C. The ecological benefit of urban forest and trees and its value. World For. Res. 2004, 17, 17-20. (In Chinese)

6. Chen, W.Y.; Jim, C.Y. Cost-benefit analysis of the leisure value of urban greening in the new Chinese city of Zhuhai. Cities 2008, 25, 298-309. [CrossRef]

7. Chen, W.Y.; Jim, C.Y. Assessment and valuation of the ecosystem services provided by urban forests. In Ecology Planning and Management of Urban Forests: International Perspectives; Carreiro, M.M., Song, Y.C., Wu, J.G., Eds.; Springer Verlag: New York, NY, USA, 2008; pp. 53-83. ISBN 978-0-387-71424-0.

8. Nowak, D.J.; Hoehn, R.E.; Bodine, A.R.; Greenfield, E.J.; O'Neil-Dunne, J. Urban forest structure, ecosystem services and change in Syracuse, NY. Urban Ecosyst. 2016, 19, 1455-1477. [CrossRef]

9. Armson, D.; Stringer, P.; Ennos, A.R. The effect of street trees and amenity grass on urban surface water runoff in Manchester, UK. Urban For. Urban Green. 2013, 12, 282-286. [CrossRef]

10. McPherson, E.G.; Simpson, J.R. A comparison of municipal forest benefits and costs in Modesto and Santa Monica, California, USA. Urban For. Urban Green. 2002, 1, 61-74. [CrossRef]

11. McPherson, E.G.; van Doorn, N.; de Goede, J. Structure, function and value of street trees in California, USA. Urban For. Urban Green. 2016, 17, 104-115. [CrossRef] 
12. Soares, A.L.; Rego, F.C.; McPherson, E.G.; Simpson, J.R.; Peper, P.J.; Xiao, Q. Benefits and costs of street trees in Lisbon, Portugal. Urban For. Urban Green. 2011, 10, 69-78. [CrossRef]

13. Xiao, Q.; McPherson, E.G. Rainfall interception by Santa Monica's municipal urban forest. Urban Ecosyst. 2002, 6, 291-302. [CrossRef]

14. Georgi, J.N.; Dimitriou, D. The contribution of urban green spaces to the improvement of environment in cities: Case study of Chania, Greece. Build. Environ. 2010, 45, 1401-1414. [CrossRef]

15. Kuruneri-Chitepo, C.; Shackleton, C.M. The distribution, abundance and composition of street trees in selected towns of the Eastern Cape, South Africa. Urban For. Urban Green. 2011, 10, 247-254. [CrossRef]

16. Nagendra, H.; Gopal, D. Street trees in Bangalore: Density, diversity, composition and distribution. Urban For. Urban Green. 2010, 9, 129-137. [CrossRef]

17. Thomsen, P.; Bühler, O.; Kristoffersen, P. Diversity of street tree populations in larger Danish municipalities. Urban For. Urban Green. 2016, 15, 200-210. [CrossRef]

18. Yang, J.; Zhou, J.; Ke, Y.; Xiao, J. Assessing the structure and stability of street trees in Lhasa, China. Urban For. Urban Green. 2012, 11, 432-438. [CrossRef]

19. Konijnendijk, C.C. The Forest and the City: The Cultural Landscape of Urban Woodland; Springer: Berlin, Germany, 2008; ISBN 978-1-4020-8370-9.

20. Mullaney, J.; Lucke, T.; Trueman, S.J. A review of benefits and challenges in growing street trees in paved urban environments. Landsc. Urban Plan. 2015, 134, 157-166. [CrossRef]

21. McPherson, G.; Simpson, J.R.; Peper, P.J.; Maco, S.E.; Xiao, Q.F. Municipal forest benefits and costs in five US cities. J. For. 2005, 103, 411-416.

22. Chang, Y.S.; Arndt, R.L.; Calori, G.; Carmichael, G.R.; Streets, D.G.; Su, H.P. Air quality impacts as a result of changes in energy use in China's Jiangsu Province. Atmos. Environ. 1998, 32, 1383-1395. [CrossRef]

23. Liu, C.; Shen, X.; Zhou, P.; Che, S.; Zhang, Y.; Shen, G. Urban forestry in China: Status and prospects. UA-Mag. 2004, 13, 15-17.

24. Zhang, Y.; Yu, X. Current research state and development of urban forestry. J. South China Univ. Trop. Agric. 2007, 13, 38-42. (In Chinese)

25. Wang, Z.; Chen, J.; Qiao, X.; Yang, P.; Tian, F.; Huang, L. Distribution and sources of polycyclic aromatic hydrocarbons from urban to rural soils: A case study in Dalian, China. Chemosphere 2007, 68, 965-971. [CrossRef] [PubMed]

26. Zhang, X.; Jiang, H.; Zhang, Q.; Zhang, X. Chemical characteristics of rainwater in northeast China, a case study of Dalian. Atmos. Res. 2012, 116, 151-159. [CrossRef]

27. McPherson, E.G. Selecting reference cities for i-Tree Streets. Arboric. Urban For. 2010, 36, 230-240.

28. Liaoning Price Bureau. Electricity Grid Tariff Schedule of Liaoning Province. 2017. Available online: http:/ / www.lnprice.gov.cn/ (accessed on 1 August 2017). (In Chinese)

29. Zhang, X.; Lou, F.; Zhang, X. Carbon emissions and economic impacts of natural gas price regulation in China: Based on the incomplete competition CGE model. China Popul. Resour. Environ. 2016, 26, 76-84. (In Chinese)

30. Du, Y. A Analysis on Community Characteristics and Benefits Comparison of Urban Landscape Woods in Hefei City. Master's Thesis, Anhui Agricultural University, Hefei, China, 2013. (In Chinese)

31. McPherson, E.G.; Simpson, J.R.; Peper, P.J.; Gardner, S.L.; Vargas, K.E.; Xiao, Q. Northeast Community Tree Guide: Benefits, Costs, and Strategic Planting; General Technical Reports PSW-GTR-202; US Department of Agriculture: Albany, CA, USA, 2007.

32. Peper, P.J.; McPherson, E.G.; Mori, S.M. Equations for predicting diameter, height, crown width, and leaf area of San Joaquin valley street trees. J. Arboric. 2001, 27, 306-317.

33. Peper, P.J.; McPherson, E.G.; Simpson, J.R.; Gardner, S.L.; Vargas, K.E.; Xiao, Q. City of New York Municipal Forest Resource Assessment; Internal Technical Report; U.S. Department of Agriculture, Forest Service, Pacific Southwest Research Station: Davis, CA, USA, 2007.

34. Millward, A.A.; Sabir, S. Structure of a forested urban park Implications for strategic management. J. Environ. Manag. 2010, 91, 2215-2224. [CrossRef] [PubMed]

35. Richard, N.A. Diversity and stability in a street tree population. Urban Ecol. 1982, 7, 159-171. [CrossRef]

36. Heisler, G.M. Energy savings with trees. J. Arboric. 1986, 12, 113-125. 
37. Heisler, G.M.; Brazel, A.J. The urban physical environment: Temperature andurban heat islands. In Urban Ecosystem Ecology. Agronomy Monograph 55; Aitkenhead-Peterson, J., Volder, A., Eds.; American Society of Agronomy, Crop Science Society of America, Soil Science Society of America: Madison, WI, USA, 2010; pp. 29-56.

38. McPherson, E.G.; Simpson, J.R. Potential energy savings in buildings by an urban tree planting programme in California. Urban For. Urban Green. 2003, 2, 73-86. [CrossRef]

39. McPherson, E.G.; Simpson, J.R. Guidelines for Calculating Carbon Dioxide Reductions and through Urban Forestry Programs; General Technical Report PSW-171; U.S. Department of Agriculture Forest Service Pacific Southwest Research Station: Albany, CA, USA, 1999.

40. Akbari, $\mathrm{H}$. Shade trees reduce building energy use and $\mathrm{CO}_{2}$ emissions from power plants. Environ. Pollut. 2002, 116, 119-126. [CrossRef]

41. McPherson, E.G.; Nowak, D.; Heisler, G.; Grimmond, S.; Souch, C.; Grant, R.; Rowntree, R. Quantifying urban forest structure, function, and value: The Chicago Urban Forest Climate Project. Urban Ecosyst. 1997, 1, 49-61. [CrossRef]

42. McHale, M.R.; Burke, I.C.; Lefsky, M.A.; Peper, P.J.; McPherson, E.G. Urban forest biomass estimates: Is it important to use allometric relationships developed specifically for urban trees? Urban Ecosyst. 2009, 12, 95-113. [CrossRef]

43. Pillsbury, N.; Thompson, R. Tree Volume Equations for Fifteen Urban Species in California; Report; Urban Forest Ecosystems Institute, California Polytechnic State University: San Louis Obispo, CA, USA, 1998.

44. Nowak, D.J. Air pollution removal by Chicago's urban forest. In Chicago's Urban Forest Ecosystem: Results of the Chicago Urban Forest Climate Project; McPherson, E.G., Nowak, D.J., Rowntree, R.A., Eds.; General Technical Report NE-186; Forest Service, USDA: Washington, DC, USA, 1994; pp. 63-81.

45. Beckett, K.P.; Freer-Smith, P.H.; Taylor, G. Urban woodlands: Their role in reducing the effects of particulate pollution. Environ. Pollut. 1998, 99, 347-360. [CrossRef]

46. Nowak, D.J.; Civerolo, K.L.; Rao, S.T.; Sistla, G.; Luley, C.J.; Crane, D.E. A modeling study of the impact of urban trees on ozone. Atmos. Environ. 2000, 34, 1601-1613. [CrossRef]

47. Nowak, D.J.; Crane, D.E.; Stevens, J.C.; Hoehn, R.E.; Walton, J.T.; Bond, J. A Ground-Based Method of Assessing Urban Forest. Arboric. Urban For. 2008, 34, 347-358.

48. Benjamin, M.T.; Winer, A.M. Estimating the ozone-forming potential of urban trees and shrubs. Atmos. Environ. 1998, 32, 53-68. [CrossRef]

49. Scott, K.I.; McPherson, E.G.; Simpson, J.R. Air pollutant uptake by Sacrameto's urban forest. J. Arboric. 1997, 24, 224-234.

50. Xiao, Q.F.; McPherson, E.G.; Ustin, S.L.; Grismer, M.E.; Simpson, J.R. Winter rainfall interception by two mature open-grown trees in Davis, California. Hydrol. Process. 2000, 14, 763-784. [CrossRef]

51. Schroeder, H.W.; Cannon, W.N. The esthetic contribution of trees to residential streets in Ohio towns. J. Arboric. 1983, 9, 237-243.

52. Wolf, K.L. Business district streetscapes, trees, and consumer response. J. For. 2005, 103, 396-400.

53. Donovan, G.H.; Butry, D.T. Market based approaches to tree valuation. Arborist News 2008, 17, 52-55.

54. Donovan, G.H.; Butry, D.T. Trees in the city: Valuing street trees in Portland, Oregon. Landsc. Urban Plan. 2010, 94, 77-83. [CrossRef]

55. Santamour, F.S., Jr. Trees for urban planting: Diversity, uniformity, and common sense. In Proceedings of the 7th Conference Metropolitan Tree Improvement Alliance (METRIA), Lisle, IL, USA, 11-12 June 1990; Morton Arboretum: Lisle, IL, USA, 1990; Volume 7, pp. 57-65.

56. Anderson, L.M.; Cordell, H.K. Influence of Trees on Residential Property Values in Athens, Georgia (USA): A survey based on actual sales prices. Landsc. Urban Plan. 1988, 15, 153-164. [CrossRef]

57. Millward, A.A.; Sabir, S. Benefits of a forested urban park: What is the value of Allan Gardens to the city of Toronto, Canada? Landsc. Urban Plan. 2011, 100, 177-188. [CrossRef]

58. Ma, N. Study on Structure and Ecological Benefits of Street Trees Based on i-Tree Model-a Case Study of Shenyang. Master's Thesis, Chinese Academy of Sciences, Beijing, China, 2011.

59. Zhang, Y.; Zhou, C.; Dong, Y.; Wang, Y. Composition and ecological benefits of street trees in Shinan District of Qingdao City, Shandong Province based on i-Tree Model. Chin. J. Ecol. 2013, 32, 1739-1747. (In Chinese) 
60. McPherson, E.G.; Gable, M.; Jahn, D.; Ames, D.; Remcheck, M. City of Pittsburgh, Pennsylvania Municipal Forest Resource Analysis; Center for Urban. Forest Research, USDA Forest Service, Pacific Southwest Research Station: Redding, CA, USA, 2008.

61. McPherson, E.G.; Kotow, L. A municipal forest report card: Results for California, USA. Urban For. Urban Green. 2013, 12, 134-143. [CrossRef]

62. Peper, P.J.; McPherson, E.G.; Simpson, J.R.; Vargas, K.E.; Xiao, Q. City of Indianapolis Municipal Forest Resource Assessment; Internal Technical Report; U.S. Department of Agriculture, Forest Service, Pacific Southwest Research Station: Davis, CA, USA, 2008.

(c) (C) 2018 by the authors. Licensee MDPI, Basel, Switzerland. This article is an open access article distributed under the terms and conditions of the Creative Commons Attribution (CC BY) license (http:/ / creativecommons.org/licenses/by/4.0/). 